\title{
PHYSICOCHEMICAL AND BACTERIOLOGICAL WATER ANALYSIS OF BAGMATI AND BISHNUMATI RIVER
}

\section{Pradeep Kumar Shah ${ }^{1}$, Shashi Bhushan Chaturwedi ${ }^{2}$}

\begin{abstract}
Water pollution, one of the serious environmental issues of the world, results from contaminants being introduced into the natural environment. This study was conducted in the Microbiology laboratory, DAV College, Dhobighat, Lalitpur, Nepal from January to May 2018 with aims to assess the physicochemical and microbiological status of river water of Kathmandu valley. All together 60 water samples were collected, 20 water samples each from different places of Bagmati river, Bishnumati river and river junction (Teku Dovan). The physicochemical parameters including $\mathrm{pH}$, ammonia and iron, hardness and alkalinity were analyzed by standard methods and the microbiological parameters such as total mesophilic count and total coliform count were analyzed by pour plate technique. Among all 60 water samples tested, the temperature $\left(12.8^{\circ} \mathrm{C}\right), \mathrm{BOD}$ value $(3.11 \mathrm{mg} / \mathrm{l})$, iron value $(0.87$ $\mathrm{mg} / \mathrm{l})$ and turbidity (102.2NTU) were found to be highest in Bagmati river water samples whereas the value of TSS (755.2 mg/l), TDS (748.4 mg/l), copper (0.01 mg/l) and COD (911.5 PPM) were found to be highest in water of Bishnumati river. The heavy meals Manganese $(0.29 \mathrm{mg} / \mathrm{l})$ and Nickel $(0.01$ $\mathrm{mg} / \mathrm{l})$ were detected only in Bishnumati river water samples. The river junction water samples showed the exceeded value of DO $(9.56 \mathrm{mg} / \mathrm{l})$ and chloride $(0.12 \mathrm{mg} / \mathrm{l})$. All the 60 samples showed total mesophilic counts more than $300 \mathrm{cfu} / \mathrm{ml}$ and the average number of total mesophilic counts were found to be $5.21 \times 10^{6} \mathrm{cfu} / \mathrm{ml}$. The average number of total coliform counts were found to be $2.1 \times 10^{5} \mathrm{cfu} / \mathrm{ml}$ in the water samples of Bagmati river, Bishnumati river
\end{abstract}

1 Mr. Shah is an Associated Professor, Department of Microbiology, Trichandra Multiple Campus, Kathmandu, TU.

2 Mr. Chaturwedi is associated with Department of Microbiology, D.A.V. College, Lalitpur. 
and river junction. Most of the tested parameter of the samples had more than the standard value of water quality indicating the deterioration of river water quality and thus may affect the aquatic as well as human and animal lives.

Keywords: Physicochemical Parameters, Total Mesophilic Counts, Total Coliform Counts, River Water, Kathmandu Valley

\section{INTRODUCTION}

Water is the most vital resource for all kinds of life on this planet and essential for ensuring the integrity and sustainability of the earth's ecosystems (UNESCO 2003). Water quality refers to the set of concentrations, speciation and physical partitions of inorganic and organic substances including the composition and state of aquatic biota in the water body. It is used to refer the suitability of water to sustain living organisms and other uses. For this, it should be suitable in terms of physical, chemical, biological and aesthetic characters (APHA 2005). When the water quality parameters shift beyond the range of water quality standards for various purposes, the water is said to be polluted. Increased human mobility, industrialization and urbanization have resulted in water pollution (DHM 2015).

The river basin currently faces a number of serious environmental and ecological challenges. Urbanization, disposal of untreated sewage, waste disposal, land encroachment, large-scale irrigation in the lower basin, and river bed mining for sand and building materials has led to water quality deterioration which has negatively impacted the river ecosystem and communities living alongside the river both in the Kathmandu valley and downstream. As a result, Bagmati river has lost its capacity of selfpurification due to various factors over the last few decades. A stress on an aquatic ecosystem can be a result of physical, chemical or biological alterations of the environment. Physical alterations include changes in water temperature, water flow and light availability. Chemical alterations include changes in the loading rates of bio stimulatory nutrients, oxygen consuming materials, and toxins. Biological alterations include overharvesting of commercial species and the introduction of exotic species (Alexander 1999). For evaluation of water quality, the water quality criteria for specific uses are required against which the parameter values obtained by testing the sample is compared. Monitoring of the quality of water for safe use requires a continuous check on physical, chemical and biological 
factors in order to get information about suitability of water and set standard for the intended purpose (GON 2016).

Polluted water is responsible for very large number of mortalities of organisms and it becomes a vehicle for transmission of diseases. It is one of the most important problems being faced by both developed and developing countries as a major cause of human disease, misery and death. It has been estimated that some 30,000 people die every day from water related disease and this kind of episode is more critical in the less developed countries (WHO 1991). While considering microbiological water quality, chlorinated water of Kathmandu is found heavily contaminated with faecal materials (Bhattarai et al. 2008). The study describes the existing status of the Bagmati and Bishnumati river in terms of physiochemical and microbiological parameters. Therefore, this study was carried out to assess physicochemical parameters and bacteriological parameters of Bagmati river, Bishnumati river and river junction water samples. This study might be suggestive of the appropriateness of water for intended use and make public aware about the probable chance of infection and other health problems associated with the use of water.

\section{MATERIALS AND METHOD}

This work was carried out from January to May, 2018. A total of 60 water samples were collected from different places of Bishnumati river, Bagmati river and river junction (Teku Dovan) in separate sterile bottles of 1 litre capacity. The collected samples were transported to the Department of Microbiology laboratory at D.A.V. College keeping into ice box at $4^{\circ} \mathrm{C}$. The Physicochemical parameters $\mathrm{pH}$ (by digital $\mathrm{pH}$ meter), ammonia and iron (by UV spectrophotometer), hardness (by titration) and alkalinity (by titration), heavy metals (by Atomic Absorbance Spectrophotometry) were analysed. For bacteriological analysis, total mesophilic counts and total coliform counts were done by pour plate technique.

\section{RESULTS}

\section{Physicochemical parameters in water samples}

Among the tested water samples, iron and turbidity was found to be highest in the Bagmati river water samples. The water samples of Bishnumati river showed highest value of TSS, TDS, copper and COD. The water samples from river junction showed highest value of chloride and hardness (Table 1). 
Table 1: Physicochemical parameters in river water samples

\begin{tabular}{|c|c|c|c|c|c|c|c|c|c|}
\hline \multirow[t]{2}{*}{$\begin{array}{l}\text { Parameters } \\
\text { (Standard } \\
\text { value) }\end{array}$} & \multicolumn{3}{|c|}{$\begin{array}{l}\text { Bishnumati river } \\
\text { Number of samples }\end{array}$} & \multicolumn{3}{|c|}{$\begin{array}{l}\text { Bagmati river } \\
\text { Number of samples }\end{array}$} & \multicolumn{3}{|c|}{$\begin{array}{l}\text { River junction } \\
\text { Number of samples }\end{array}$} \\
\hline & 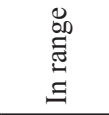 & 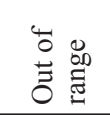 & 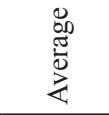 & 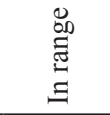 & 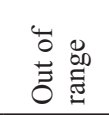 & $\begin{array}{l}\mathscr{D}_{0} \\
\frac{\pi}{0} \\
\sum^{2}\end{array}$ & $\begin{array}{l}\stackrel{.0}{6} \\
\stackrel{5}{\leftrightarrows} \\
\Xi\end{array}$ & 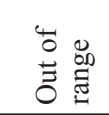 & 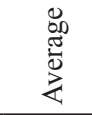 \\
\hline $\begin{array}{l}\text { Temperature } \\
\left(14^{\circ} \mathrm{C}-22^{\circ} \mathrm{C}\right)\end{array}$ & $0(0 \%)$ & $\begin{array}{l}20 \\
(100 \%)\end{array}$ & 12.57 & $0(0 \%)$ & $\begin{array}{l}20 \\
(100 \%)\end{array}$ & 12.8 & $0(0 \%)$ & $\begin{array}{l}20 \\
(100 \%)\end{array}$ & 12.78 \\
\hline $\begin{array}{l}\mathrm{pH} \\
(6.5-9)\end{array}$ & $\begin{array}{l}20 \\
(100 \%)\end{array}$ & $0(0 \%)$ & 7.6 & $\begin{array}{l}20 \\
(100 \%)\end{array}$ & $0(0 \%)$ & 7.6 & $\begin{array}{l}20 \\
(100 \%)\end{array}$ & $0(0 \%)$ & 7.6 \\
\hline $\begin{array}{l}\text { TSS } \\
(100- \\
220 \mathrm{mg} / \mathrm{l})\end{array}$ & $0(0 \%)$ & $\begin{array}{l}20 \\
(100 \%)\end{array}$ & 755.2 & $\begin{array}{l}8 \\
(40 \%)\end{array}$ & $\begin{array}{l}12 \\
(60 \%)\end{array}$ & 297 & $\begin{array}{l}10 \\
(50 \%)\end{array}$ & $\begin{array}{l}10 \\
(50 \%)\end{array}$ & 468.2 \\
\hline $\begin{array}{l}\text { TDS } \\
(2000 \mathrm{mg} / \mathrm{l})\end{array}$ & $\begin{array}{l}20 \\
(100 \%)\end{array}$ & $0(0 \%)$ & 748.4 & $\begin{array}{l}20 \\
(100 \%)\end{array}$ & $0(0 \%)$ & 533 & $\begin{array}{l}20 \\
(100 \%)\end{array}$ & $0(0 \%)$ & 485 \\
\hline $\begin{array}{l}\text { COD } \\
(100 \mathrm{mg} / \mathrm{l})\end{array}$ & $0(0 \%)$ & $\begin{array}{l}20 \\
(100 \%)\end{array}$ & 911.5 & $0(0 \%)$ & $\begin{array}{l}20 \\
(100 \%)\end{array}$ & 792.8 & $0(0 \%)$ & $\begin{array}{l}20 \\
(100 \%)\end{array}$ & 504.3 \\
\hline $\begin{array}{l}\text { Turbidity } \\
\text { (5 NTU) }\end{array}$ & $0(0 \%)$ & $\begin{array}{l}20 \\
(100 \%)\end{array}$ & 36.4 & $0(0 \%)$ & $\begin{array}{l}20 \\
(100 \%)\end{array}$ & 102.2 & $0(0 \%)$ & $\begin{array}{l}20 \\
(100 \%)\end{array}$ & 93.6 \\
\hline $\begin{array}{l}\text { Chloride } \\
(0001- \\
0.008 \mathrm{mg} / \mathrm{l})\end{array}$ & $0(0 \%)$ & $\begin{array}{l}20 \\
(100 \%)\end{array}$ & 0.107 & $0(0 \%)$ & $\begin{array}{l}20 \\
(100 \%)\end{array}$ & 0.104 & $0(0 \%)$ & $\begin{array}{l}20 \\
(100 \%)\end{array}$ & 0.1094 \\
\hline $\begin{array}{l}\text { Hardness } \\
(<500 \mathrm{mg} / \mathrm{l})\end{array}$ & $\begin{array}{l}20 \\
(100 \%)\end{array}$ & $0(0 \%)$ & 431.4 & $\begin{array}{l}20 \\
(100 \%)\end{array}$ & $0(0 \%)$ & 272 & $\begin{array}{l}20 \\
(100 \%)\end{array}$ & $0(0 \%)$ & 452.9 \\
\hline $\begin{array}{l}\text { Iron } \\
(1 \mathrm{mg} / \mathrm{l})\end{array}$ & $\begin{array}{l}20 \\
(100 \%)\end{array}$ & $0(0 \%)$ & 0.3938 & $\begin{array}{l}18 \\
(90 \%)\end{array}$ & $2(10 \%)$ & 0.8697 & $\begin{array}{l}20 \\
(100 \%)\end{array}$ & $0(0 \%)$ & 0.5827 \\
\hline $\begin{array}{l}\text { Copper } \\
(0-250 \mathrm{mg} / \mathrm{l})\end{array}$ & $\begin{array}{l}20 \\
(100 \%)\end{array}$ & $0(0 \%)$ & 0.01167 & $\begin{array}{l}20 \\
(100 \%)\end{array}$ & $0(0 \%)$ & 0 & $\begin{array}{l}20 \\
(100 \%)\end{array}$ & $0(0 \%)$ & 0.0103 \\
\hline $\begin{array}{l}\text { Manganese } \\
(0.4 \mathrm{mg} / \mathrm{l})\end{array}$ & $0(0 \%)$ & $\begin{array}{l}20 \\
(100 \%)\end{array}$ & 0.286 & $\begin{array}{l}20 \\
(100 \%)\end{array}$ & $0(0 \%)$ & 00 & $\begin{array}{l}20 \\
(100 \%)\end{array}$ & $0(0 \%)$ & 0 \\
\hline Nickel & $0(0 \%)$ & $\begin{array}{l}20 \\
(100 \%)\end{array}$ & 0.0142 & $0(0 \%)$ & $\begin{array}{l}20 \\
(100 \%)\end{array}$ & 0 & $0(0 \%)$ & $\begin{array}{l}20 \\
(100 \%)\end{array}$ & 0 \\
\hline $\begin{array}{l}\text { Chromium } \\
(<.21 \mathrm{mg} / \mathrm{l})\end{array}$ & $\begin{array}{l}20 \\
(100 \%)\end{array}$ & $0(0 \%)$ & 0 & $\begin{array}{l}20 \\
(100 \%)\end{array}$ & $0(0 \%)$ & 0 & $\begin{array}{l}20 \\
(100 \%)\end{array}$ & $0(0 \%)$ & 0 \\
\hline
\end{tabular}

Sources: Environment Statistics of Nepal 2008, Government of Nepal, National Planning Commission Secretariat, Central Bureau of Statistics, Kathmandu, Nepal Environmental Standards and Related Information Booklet (August, 2010), Ministry of Environment, Nepal Government

\section{Microbiological parameters}

The DO value and BOD value for all the tested water samples were found to be out of range as given by WHO guideline ( $\mathrm{DO}=>5 \mathrm{mg} / \mathrm{l}$, $\mathrm{BOD}=5-9 \mathrm{mg} / \mathrm{l})$. The average number of total mesophilic counts of all the tested water samples were found to be $5.21 \times 10^{6} \mathrm{cfu} / \mathrm{ml}$ whereas the average 
number of total coliform counts was found to be $2.1 \times 10^{5} \mathrm{cfu} / \mathrm{ml}$ in the water samples of Bagmati river, Bishnumati river and river junction.

\section{DISCUSSION}

The average $\mathrm{pH}$ of Bishnumati, Bagmati and river junction water samples were found to be 7.6 which were within the range as described by WHO standard. The total suspended solid (TSS) of all the water samples of Bishnumati river exceeded the WHO standard value while $50 \%$ of river junction water samples were within the range of TSS standard value. This may be due to the decomposition of suspended matter including domestic garbage and other waste materials. The TDS values in the entire samples were within the range as prescribed by WHO standard value. The COD value of all the water samples did not fall in the standard range as given by WHO standards. This might be due to presence of higher amount of organic matters present in the river water. This result was in accordance with the study of Paudyal et al. (2016).

The turbidity value of Bishnumati, Bagmati and river junction water samples were out of range as recommended by WHO standard. Increased turbidity affects the photosynthetic process of aquatic plants. All the water samples tested, consisted high chloride concentration than the standard value given by FAO (1973). The high chloride concentration is considered to be the indicator of high organic waste pollution in the river. Water with high chloride is carcinogenic (WHO 2007). The iron and the copper values of most of the water samples tested were found within the range as recommended by the WHO (2007) and EU (1979). These values of iron and copper coincided by the study carried out by KC et al. (2018).

The manganese and chromium content in all the water samples tested were within the standard value given by EU (1979) and USEPA (1993). However all the water samples examined showed higher nickel value than standard.

The water samples of Bagmati river and river junction had the DO value within the WHO standard. However, the average DO value of Bishnumati river water samples was found to be less than the WHO standard. This might be due to the contamination of waste materials in water bodies. The total number of mesophilic bacteria and coliform bacteria were found to be very high in all the water samples examined. This indicated the deteriorating water quality which may contribute water borne diseases in community as reported by Rai et al, (2012) and KC et al. (2018). 


\section{CONCLUSION}

The water of Bishnumati, Bagmati and river junction were found to be highly contaminated and polluted which can be considered not to fit for human use and aquatic life. The water of Bagmati river, Bishnumati river as well as river junction can be utilized for various purposes only after proper treatment.

\section{ACKNOWLEDGEMENT}

We would like to express our gratitude towards the Department of Microbiology, D.A.V. College, Lalitpur, Nepal for kind cooperation during this work.

\section{REFERENCES}

Alexander, DE. (1999). Encyclopaedia of environmental science. Springer, ISBN 0-412-74050-8

APHA. (2005). Standard methods for the examination of water and waste water, 21st Edition. American Public Health Association, Washington, DC

Bhattarai, K., Shrestha, B. \& Lekhak, H. (2008). Water quality of Sundarijal reservoir and its feeding streams in Kathmandu. Scientific World 6(6): 99-106. https://doi.org/10.3126/sw.v6i6.2643

Chapman, D. (1993). Water quality assessment. A Guide to the Use of Bota, Sediment and Water in Environment Monitoring, WHO, Geneva, 626.

Devkota, D. \& Watanabe, K. (2005). Impact of solid waste on water quality of Bishnumati river and surrounding areas in Kathmandu, Nepal. Journal of Nepal Geological Society 31: 19-24

Devkota, SR. \& Neupane, CP. (1994). Industrial pollution inventory of the Kathmandu valley and Nepal. Report prepared by the Industrial Pollution Control Management Project, Ministry of Industry, Kathmandu. pp. 37-42

DHM. (2015). Study of climate and climatic variation over Nepal. Department of Hydrology and Meteorology, Ministry of Population and Environment, Nepal.

ENPHO. (2002). Kathmandu city looking through the eye of ENPHO. Environment and Public Health Organization a Decade, $10^{\text {th }}$ Anniversary Souvenir. Kathmandu, ENPHO, Environment and Public Health Organization. pp. 65-73 
GON. (2008). Environment statistics of Nepal. Central Bureau of Statistics, National Planning Commission Secretariat, Government of Nepal, Kathmandu, Nepal.

EU. (1979). Drinking water directive 98/83/EC. European Union. http:// europa.eu.int/comm/environment/water/water-drink/index.en.html (accessed: December 2004)

FAO. (1973). A framework for land evaluation. Draft edition, Food and Agriculture Organization, The United Nations, AGL/MISC/73/14, Rome, pp. 65.

GON. (2005). National drinking water quality standard. Ministry of Physical Planning and Works, Kathmandu, Government of Nepal, WHO/DWSS (World Health Organization/department of Water Supply and Sewar), 2-9. http://www.unesco.org/new/en/naturalsciences/environment/water/wwap/wwdr/wwdr1-2003/

KC, S., Gurung, A., Chaulagain, L., Amagain, S., Ghimire, S. \& Amatya, J. (2018). Physicochemical and bacteriological analysis of Bagmati river in Kathmandu valley. Annals of Applied Bio-Sciences 5(3): 24552461

NHMRC. (2001). Microbial indicator of water quality. Discussion paper, National Health and Medical Research Council, Common Wealth of Australia, (12): pp. 1130.

Park, K. (2005). Environment and Health. In: Park's textbook of preventive and social medicine. $18^{\text {th }}$ Edition $\mathrm{M} / \mathrm{S}$ Banarsidas Bhanot, Premnagar India, pp. 519-542

Paudyal, R., Sharma, CM., Tripathee, L. \& Sillanpaa, M. (2016). Variations of the physicochemical parameter and metal levels and their risk assessment in urbanized Bagmati river, Kathmandu, Nepal, Journal of Chemistry, 1-14.

Rai, SK., Ono, K., Yanagida, JI., Imura, S., Kurokawa, M. \& Rai, CK. (2012). A large-scale study of bacterial contamination of drinking water and its public health impact in Nepal. Nepal Med Coll J. 14(3): 234-240

UNESCO. (2003). Water for people, water for life. United Nations World Water Development Report, United Nations Educational, Scientific and Cultural Organization.

UNICEF. (2008). Unicef handbook on water quality. United Nations Children's Fund, UN Plaza, Network, pp. 140. 
USEPA. (2006). Distribution system indicators of drinking water quality. United States Environmental Protection Agency, Washington DC, pp. 816-1003.

WHO. (1991). The challenge ahead. WHO/PEP/91.2, World Health Organization, Geneva.

WHO. (1993). Guidelines for drinking water quality. World Health Organization, Geneva, (2): pp. 304-441.

WHO. (1996). Guidelines for drinking water quality. World Health Organization, pp. 170-200.

WHO. (2004). Guidelines for drinking water quality. World Health Organization, Geneva, (1): pp. 45-68.

WHO. (2006). Guidelines for drinking water quality. $1^{\text {st }}$ Edition, World Health Organization, Geneva, (1): pp. 1-8.

WHO. (2007). Health through safe drinking and basic sanitation. World Health Organization, Geneva, World Health Forum Bulletin. 